Article

\title{
Communication on Sustainability in Spanish Universities: Analysis of Websites, Scientific Papers and Impact in Social Media
}

\author{
Daniela De Filippo ${ }^{1,2, * \mathbb{C}}$, Javier Benayas ${ }^{1,3}$, , Karem Peña ${ }^{4}$ and Flor Sánchez ${ }^{1,4}$ \\ 1 Research Institute for Higher Education and Science (INAECU), 28903 Madrid, Spain; \\ javier.benayas@uam.es (J.B.); flor.sanchez@uam.es (F.S.) \\ 2 Department of Library Science and Documentation, University Carlos III, 28903 Madrid, Spain \\ 3 Department of Ecology, Autonomous University of Madrid, 28049 Madrid, Spain \\ 4 Department of Social Psychology, Autonomous University of Madrid, 28049 Madrid, Spain; \\ karemeyde@gmail.com \\ * Correspondence: dfilippo@bib.uc3m.es
}

Received: 31 August 2020; Accepted: 6 October 2020; Published: 8 October 2020

\begin{abstract}
This study analyses how Spanish universities are communicating their commitment to sustainability to society. That entailed analysing the content of their websites and their scientific papers in sustainability science and technologies and measuring the impact of such research in social media. Results obtained from bibliometric approaches and institutional document analysis attest to intensified interest in sustainability among Spanish universities in recent years. The findings revealed an increase in the number of universities using terms associated with sustainability to designate the governing bodies. The present study also uses an activity index to identify universities that devote high effort to research on sustainability and seven Spanish universities were identified with output greater than 3\% of the total. Mentions in social media were observed to have grown significantly in the last 10 years, with $38 \%$ of the sustainability papers receiving such attention, compared to $21 \%$ in 2010. Publications in open access journals have had a greater impact on social media, especially on Twitter and Facebook. The analysis of university websites showed that only $30 \%$ had social media accounts and only $6 \%$ blogs specifically designed to disseminate their sustainability activities.
\end{abstract}

Keywords: Spanish universities; communication on sustainability; university websites; bibliometric indicators; social media

\section{Introduction}

Universities are powerful influencers in their geographic and cultural surroundings. In 2017, 19.8 million students and 1.5 million professors engaged in higher education in Europe, investment in which amounted to $1.2 \%$ of the country's GDP [1]. Higher education institutions (HEIs) disseminate knowledge and innovation and further development and citizen well-being in their communities. Universities can build students' skills and heighten their awareness of sustainability by including it as a cross-curricular topic [2]. This privileged role has focused attention on universities' significant influence in the development and dissemination of sustainability [3-12]. Reciprocally, sustainability has become increasingly important for HEIs. A growing number of such institutions are embedding sustainability into curricula, research, administration, community involvement and partnerships [13-16], after having been clearly acknowledged as key actors in the development of sustainable campuses and societies [17,18].

Universities have been assuming international commitments on sustainability for decades $[19,20]$. The United Nations' Agenda 2030 [21] and its 17 sustainable development goals (SDGs) establish 
terms of reference for in-depth exploration of sustainability issues in the near future. The new agenda has also generated considerable expectation around universities' responsibilities and involvement in compliance with its provisions. These new challenges create a need to align universities' primary missions and operations with the delivery of education that drives sustainability and removes existing barriers [8,22-27]. Such involvement would call on universities the world over to continue to drive sustainable development as they have in recent decades by implementing the respective policies and programmes, along with methodologies for assessing their impact $[5,13,24,28-30]$. Spanish universities have also worked intensively toward sustainability. Already in 2010, Barañano [31] carried out a survey to analyse the commitment and contribution of Spanish universities to sustainable development. The study identified the name and type of administrative units in the universities that were dealing with the issue of sustainability, as well as the initiatives and good practices that were being carried out. Another example is to be found in the Conference of Spanish Vice-Chancellors' (Spanish acronym: CRUE) Sustainability Commission, which publishes a yearly diagnosis based on 140 indicators of the contribution of 30 Spanish universities to sustainability policies and programmes, along with methodologies for assessing their impact [32]. The aim is to detect the strengths and weaknesses of a series of universities to identify partnering strategies that would enable them to progress jointly and more quickly toward sustainability goals.

One of the conclusions that can be drawn from the literature is that sustainability measures may maintain and heighten the connection between universities and citizens. HEIs may play a significant role in societies' engagement with sustainability [33,34]. From their position of privilege, universities may alert, inform and involve citizens in their communities and society as a whole in the roll-out of and compliance with sustainability commitments defined on a worldwide scale, such as the recent Agenda 2030. That calls for effective communication with citizens around such activities, however. The influencer role that may be played by universities depends on systematic communication with quantifiable effects.

Sustainability reporting and its assessment could be a powerful strategy to evaluate, inform and manage the economic, social and environmental impact of a university [30]. One of the methods used to reveal universities' degree of involvement with sustainability is the analysis of the information appearing on their websites. Although such sites do not always accurately mirror universities' actual sustainability performance, they are a good and speedy source of reliable information on the sustainability indicators that serve for inter-university comparisons. Along these lines Dade and Hassenzahl [35] analysed the websites of 700 HEIs in the United States, whilst Son-Turan and Lambrechts [36] used a similar method to analyse eight public and private universities in Turkey. More recently, Amey et al. [37] reviewed 95 Canadian universities' use of their websites to inform about sustainability matters.

Analysing the efficacy of Spanish universities' communication is one of the challenges addressed in the present article.

The primary aim of this study was to determine how Spanish universities are communicating their commitment to sustainability and Agenda 2030 to society. That entailed analysing the content of their websites and their internationally published research in sustainability science and technologies and measuring the impact of such research in social media.

The specific research questions posed were as follows:

- Have Spanish universities intensified their sustainability commitments in terms of both policy and research?

- Can new indicators be identified to assess and conduct inter-university comparisons to establish progress in these areas?

- What strategies do universities deploy to communicate their sustainability-related activities to society? 
To answer these questions, the Information Metric's Studies described in the following section are used as a conceptual and methodological framework.

\section{Materials and Methods}

Data were collected by searching the following sources for information on the indicators specified:

University websites: Spanish universities' institutional websites were visited to ascertain whether they contain references to sustainability or Agenda 2030, applying indicators to analyse university initiatives or documents, including: management position titles, governing body structure, publication of reports and action plans, existence of specific pages or channels for communicating sustainability matters.

Scientific papers: As publication is the vehicle used to convey research findings to the academic community, the papers published by Spanish universities and listed in the international multi-disciplinary database Web of Science were analysed to determine how sustainability-related findings are disseminated.

Social media: The impact of Spanish universities' sustainability output in social media was also analysed by studying mentions of these papers in sources such as Facebook, Twitter, Wikipedia, scientific blogs and YouTube.

University rankings: University rankings such as GreenMetric (2019 edition) were likewise reviewed to determine university presence and position. Participation in a ranking was assumed to form part of institutional policy and an indicator of the image universities wish to portray to society in connection with their commitment to sustainability.

\subsection{Sample and Scope of Study}

The population for the study comprised the 75 public and private universities in the Spanish university system forming part of the Conference of Spanish Vice-Chancellors (Spanish acronym, CRUE), whose combined enrolment is on the order of one million students (Universidad en cifras, 2019) [38]. The websites of 50 institutions were analysed to ensure comparability with the Barañano survey performed in 2010 in the same population [31] and explore variations in universities' sustainability-related communication over the last decade. That list of 50 included all the universities participating in the GreenMetric sustainability ranking for 2019 [39]. Therefore, the sample analysed includes the universities with the highest degree of involvement in sustainability, leaving out those smaller or younger universities with less interest in these issues.

\subsection{Analytical Method}

To analyse how universities communicate their activities on sustainability, the methodologies of the field of information metrics studies have been used as an analytical framework. These disciplines use mathematical and statistical methods to quantify information from different sources and analyse activity patterns [40]. This paper specifically uses webmetric techniques (analysis of web pages to detect relationships, word frequencies, etc), bibliometrics (study of scientific publications) and altmetrics (indicators to measure the impact of research on social media and the Internet).

The selection of this methodology is due to the fact that the predominant model for the production and evaluation of academic knowledge revolves around the dissemination of research results in the form of published articles and patents [41]. Until only a few years ago, scientometrics and bibliometrics provided the tools of choice for analysing scientific productivity and studying the impact of research within the academic community. Although they are consolidated disciplines for studying scientific output and impact, the traditional model of scientific dissemination has been revolutionised by the institution of the Web 2.0 and the furtherance of inter-individual online communication and collaboration. Fora, blogs and social media, such as Facebook and Twitter, that have proven to be so popular among the public at large, have also influenced the members of the scientific community, giving rise to a so-called "academic social network". The proliferation of informal communication 
vehicles poses a new challenge for the analysis of scientific activity that calls for new approaches to the issue [42]. One might consist in supplementing traditional scientometric studies with the formulation of altmetric indicators that constitute a measure of public interest in research, development and innovation in a particular area [43].

The study was divided into the four stages ( $a, b, c$ and $d)$, described below.

\section{(a) Website Content}

To carry out this analysis, the methodology defined by Ott et al. [44] for the analysis of US university websites was taken as a reference. Furthermore, a study on Canadian universities [45] has served as inspiration for specific searches on the websites. To analyse the content of these web pages, terms based on Barañano's study [31] were defined and complemented with more current keywords obtained by consulting local experts. In this line, a sustainability landing page was defined as one including the terms "sustainable development", "social responsibility", "SDG", "Agenda 2030" or "environment".

This analysis was conducted in April and May 2020. The presence or absence of a sustainability landing page on university institution's website was coded. An initial pilot study was performed to gather information on three universities to define and fine-tune the criteria to be used to analyse content. Information related to sustainability was sought using both the search engines on the sites themselves and by manually visualising the pages on and structure of each university's site. The data collected with the two strategies sufficed to complete and validate the information compiled, although in most cases the manual searches delivered fuller and more reliable information.

Sustainability content was analysed on the grounds of 16 indicators grouped under three headings: (i) sustainability management structure and policy; (ii) location of sustainability content on the website; (iii) sustainability-related communication strategies.

(i) Sustainability management structure and policies. With a view to analysing universities' degree of commitment to sustainability, five indicators or search criteria were used to identify the presence or otherwise of the following items:

deputy vice-chancellorship with a title specifically related to sustainability

sustainability management office or unit

sustainability report or schedule

report devoted specifically to sustainability

participation in the 2019 edition of the GreenMetric World Ranking.

(ii) Location of sustainability content on universities' websites. Eight indicators were applied to detect the positioning of sustainability-related matters in website structure. They covered both the location of the content and the existence of:

sustainability content on home page

sustainability content in the section on university principles and objectives

sustainability content on secondary pages

page or sections on sustainable development

page or sections on social responsibility

page or sections on the environment

page or sections on Agenda 2030 and SDG

general information on Agenda 2030, even in the absence of pages specifically dealing with the subject.

(iii) Sustainability communication strategies used by the university to connect with the academic community or society were analysed on the grounds of three indicators:

use of social media 
existence of a specific institutional blog on sustainability

existence of a news channel carrying information on the university's sustainability action.

The information gathered was coded as (1) to denote the presence or (0) the absence of data under each indicator. The degree of website overall efficacy in conveying a university's sustainability measures or policies was assessed by summing the values for all the indicators as a whole. A value of 1 was assigned for every occurrence of the indicator on the site.

\section{(b) Sustainability Governance Structures}

A content analysis was conducted of the terms appearing on the websites of the universities studied to identify the titles of the deputy vice-chancellorships or administrative units entrusted with sustainability management. The findings were compared to the titles given this type of administrative unit in the universities included in the Barañano survey [31]. The aim was to identify variations over the last 10 years in the titles of the management positions responsible for sustainability in universities.

\section{(c) Scientific Papers}

Analysis focused on the papers listed under the subject category "Green \& Sustainable Science \& Technology". According to the definition given in the database itself, "This category covers resources that focus on basic and applied research on green and sustainable science and technology, including green chemistry; green nanotechnology; green building; renewable and green materials; sustainable processing and engineering; sustainable policy, management and development; environmental and agricultural sustainability; renewable and sustainable energy; and innovative technologies that reduce or eliminate damage to health and the environment" (Clarivate Analytics, 2020).

The Web of Science advanced search function was used to retrieve all Spanish papers on sustainability published in 2000-2019, with the following search strategy:

$\mathrm{WC}=$ Green \& Sustainable Science \& Technology AND CU $=$ Spain

All papers in all the Web of Science core collection indexes were collected, with no restriction placed on document type or language to provide for the broadest coverage possible. The full set of Spanish papers was then searched for the ones bearing the signature of at least one Spanish university. All the papers were downloaded and a relational database built from which data on the following indicators were drawn:

Number of papers produced by Spanish universities per year

university contribution to overall Spanish output

output per university

journals most used

accessibility of output: number of open access papers

subject specialisation.

Vosviewer software was deployed to analyse the terms used in the papers to establish the keywords and clusters and thereby define the topics most widely covered.

\section{(d) Social Media}

The social impact of scientific papers on sustainability listed in the Web of Science was measured by entering their respective digital object identifiers (DOI) into a script developed by the Carlos III University of Madrid's Metrics Studies Laboratory. The altmetric indicators were then found with the Altmetric.com tool. The following information was gathered:

Number of papers with mentions in social media

Number of mentions received by each paper

$\%$ of mentions in each social media

institutions with the most mentions 
$\bigcirc \quad$ journals with the most mentions

Although the term "social media" refers to a specific type of source, such as Facebook or Twitter, in scientometrics it has been broadened to mean the sources analysed by Altmetric.com. That broader meaning was adopted in this study.

\section{Results}

The findings relevant to the research aims pursued are discussed below.

\subsection{Analysis of University Website Content}

Figure 1a-c shows the most prominent overall findings based on the indicators applied to analyse Spanish universities' websites. The indicators on sustainability management structure and policies revealed that $82 \%$ to $88 \%$ of the universities had deputy vice-chancellorships and offices dealing with sustainability, environmental or social responsibility management. A similar percentage had an action plan to address these subjects in their management policies and action; $58 \%$ of the institutions analysed reported the results in a general or specific report. An even smaller percentage (under 54\%) committed to assessment and acknowledgment procedures through participation in a ranking system to disclose the institution's achievements in this respect. The findings are an indication that Spanish higher education institutions are devoting substantial effort to sustainability and to conveying their commitment to society at large. These results would more than likely be less optimistic if they embraced all the country's universities, for the study focused on the institutions most deeply committed to sustainability.

Further to the analysis of the position of sustainability-related topics on the website, only $24 \%$ of the universities analysed contained a mention on the home page, although those matters appeared in the sections on institutional aims and mission in $50 \%$ of the sites. They were relegated to secondary web pages in only $26 \%$ of the sample. Social responsibility was the area most frequently assigned a specific web page (52\%), followed by sustainability $(32 \%)$, whereas pages referring to the environment were scarcely found, appearing on only $8 \%$ of the sites. Interestingly, not a single Agenda 2030-specific web page was observed on any university's site, although $60 \%$ of the sites carried information on the subject. These data stand as proof that although Spanish universities are making significant strides in this regard, they are still in the process of introducing strategies for communicating new Agenda 2030-related items.

The aforementioned findings are supported by the data gathered on the use of social media to convey sustainability matters. Whilst $92 \%$ of the universities have news channels on their websites to disseminate progress in the area, specific social media accounts were found for only $32 \%$ and specific blogs for only $6 \%$.

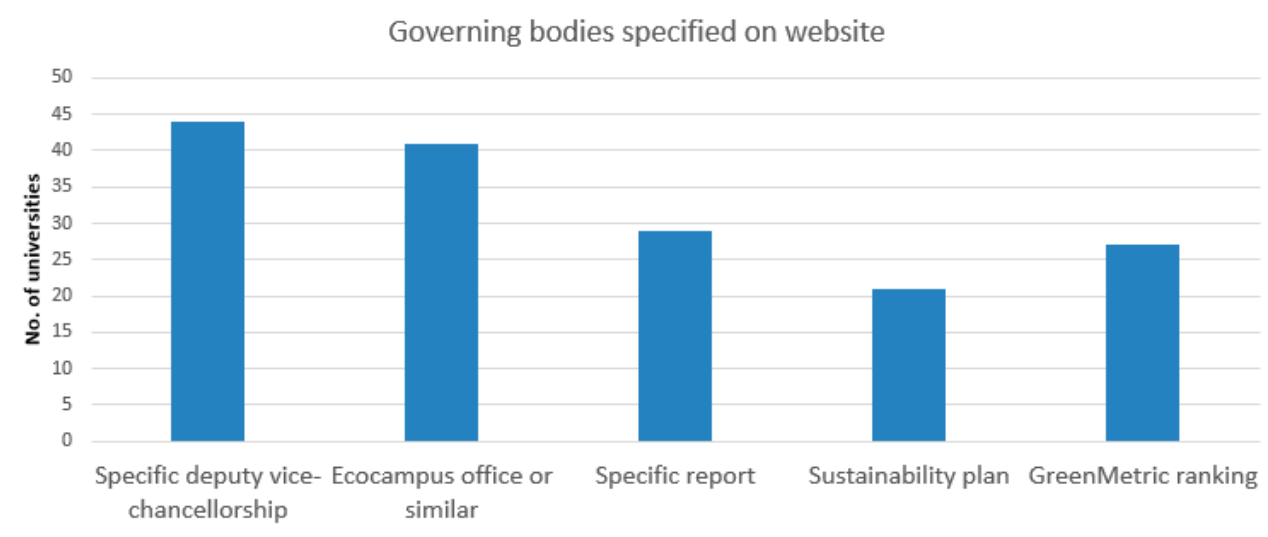

(a)

Figure 1. Cont. 


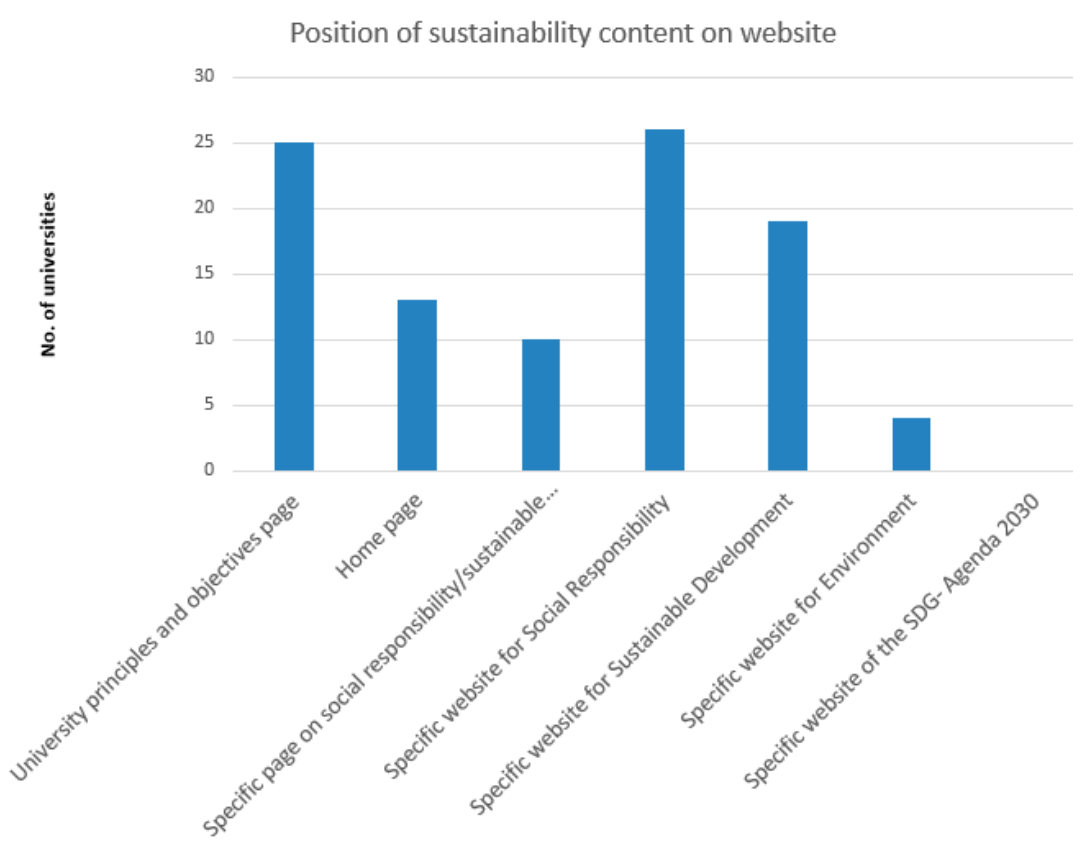

(b)

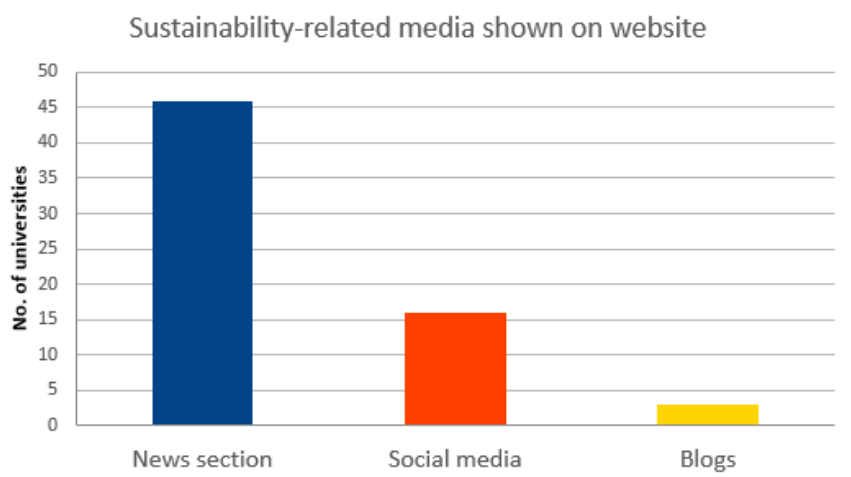

(c)

Figure 1. Percentage of universities complying with the indicators defined to analyse their websites; (a) Governing bodies specified on website; (b) Position of sustainability content on website; (c) Sustainability-related media shown on website.

\subsection{Sustainability Governance Structures}

A comparison of the keywords found in the titles of Spanish university deputy vice-chancellorships in 2020 to the results of a study conducted in 2010 [38] revealed a fairly pronounced change. In 2010, only 26 of the 50 universities studied had a deputy vice-chancellorship with a title related to sustainability, whereas in 2020 such terms were observed in 46.

The analysis was also indicative of a trend in the keywords most frequently used to identify these positions. The terms "sustainability" and "social responsibility" were the most commonly observed in both cases, with the number of universities containing the reference and the frequency of appearance doubling since 2010, whereas the words "campus" and "cooperation" remained flat or declined and the word "environment" disappeared almost altogether in the title of this management body. In contrast, the presence of the term "equality" rose substantially and new terms, such as "healthful" and "diversity" were observed (Figure 2). Those findings attest to Spanish universities' sensitivity to the inclusion in their management structures of terminology relating to the issues addressed in Agenda 2030 and the 17 new sustainable development goals. As mentioned, the importance of such variations in terminology is not merely aesthetic or institutional image-related, but lies in the changes denoted in the university's management structure. 


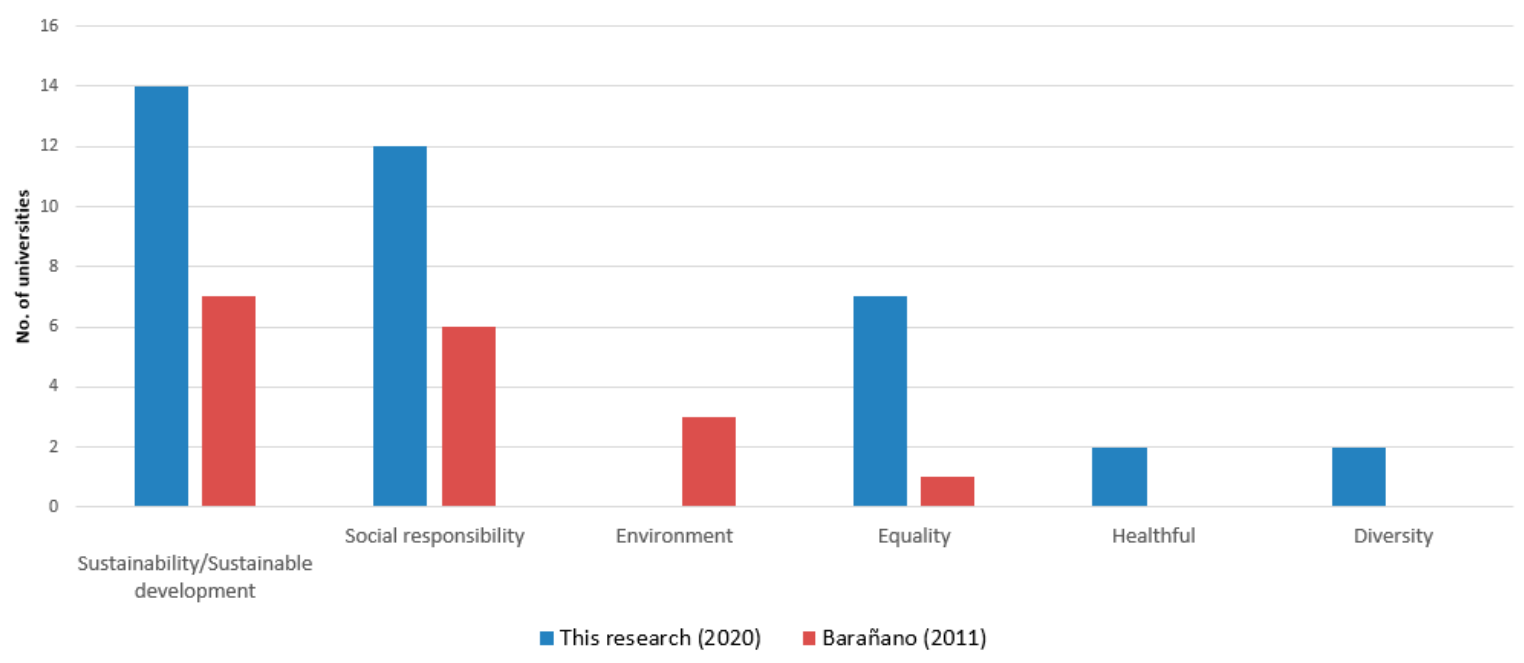

Figure 2. Variation in the titles of sustainability-related deputy vice-chancellorships and administrative units.

\subsection{Scientific Papers}

In the period analysed (2000-2019), a total of 7161 Spanish papers on sustainability were published in journals listed in the Web of Science database. Output rose steeply in the last 5 years of the series, when three-fourths of the papers were published.

Of that total output, 6084 papers or $85 \%$ were authored by universities (Figure 3), for a compound annual growth rate of $32 \%$ over the last 20 years. That attests to the pivotal role of higher education in sustainability-related science.

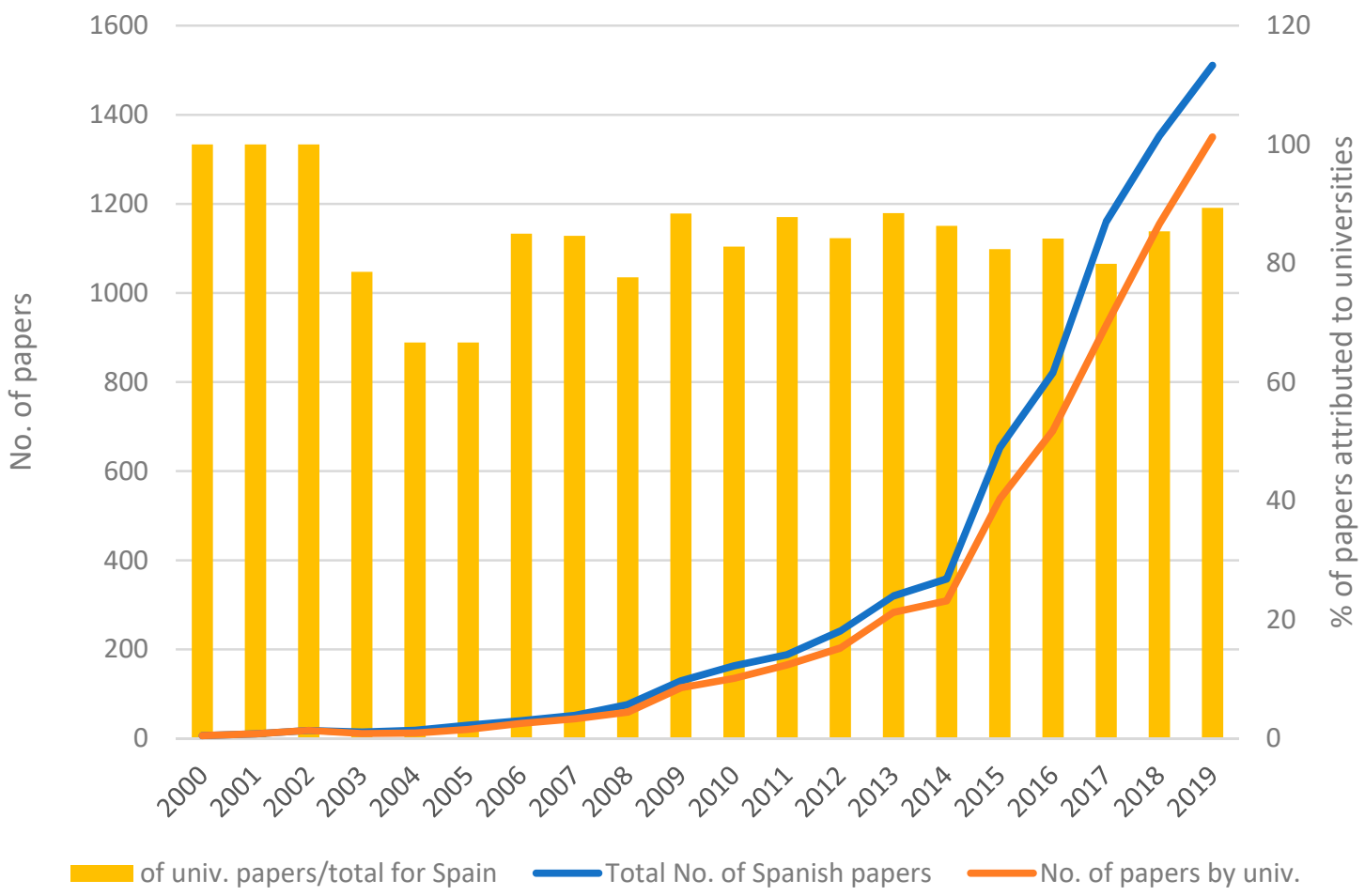

Figure 3. Spanish and Spanish university output on sustainability, 2000-2019 (Web of Science 2000-2019).

The Spanish institution with the highest output over the country total was the National Research Council (382 papers), a logical result given that the Council has greater than 100 research institutes under its aegis. By individual category, however, universities were the most active. The list was headed by the Technical Universities of Madrid, Valencia and Catalonia. Output in number of papers 
by university and by percentage of the university total, along with the activity index (AI), are given in Table 1. AI was calculated as the institution's contribution to sustainability relative to its contribution to all fields. Hence, AI values greater than 1 indicated higher than expected intensity in sustainability. The National Research Council's output, with AI less than 1, was not intense, whereas a considerable majority of the universities exhibited AI values greater than 1. AI was particularly high for the Universities of Almería, Murcia, Lleida, La Rioja, Cordoba, Jaen and the Technical University of Cartagena, all of which devoted greater effort to research in sustainability than in other subject areas.

Table 1. "Green \& Sustainable Science \& Technology" output by university (>50 papers) (Web of Science 2000-2020).

\begin{tabular}{|c|c|c|c|}
\hline Institution & No Papers & $\%$ & AI \\
\hline National Research Council & 382 & 6.28 & 0.45 \\
\hline Technical University of Madrid & 374 & 6.15 & 2.55 \\
\hline Technical University of Valencia & 348 & 5.72 & 2.30 \\
\hline Technical University of Catalonia & 342 & 5.62 & 2.01 \\
\hline Autonomous University of Barcelona & 335 & 5.51 & 1.06 \\
\hline University of Seville & 322 & 5.29 & 1.70 \\
\hline University of the Basque Country & 308 & 5.06 & 1.69 \\
\hline University of Granada & 271 & 4.45 & 1.26 \\
\hline University of Zaragoza & 266 & 4.37 & 1.83 \\
\hline University of Cordoba & 263 & 4.32 & 3.53 \\
\hline University of Santiago de Compostela & 202 & 3.32 & 1.50 \\
\hline University of Castille-La Mancha & 198 & 3.25 & 2.23 \\
\hline University of Almeria & 187 & 3.07 & 4.87 \\
\hline Rovira i Virgili University & 168 & 2.76 & 1.96 \\
\hline University of Oviedo & 167 & 2.74 & 1.46 \\
\hline University of Jaen & 162 & 2.66 & 3.48 \\
\hline University of Barcelona & 159 & 2.61 & 0.32 \\
\hline University of Vigo & 158 & 2.60 & 1.81 \\
\hline University of Extremadura & 156 & 2.56 & 2.38 \\
\hline University of Lleida & 151 & 2.48 & 4.03 \\
\hline Complutense University of Madrid & 150 & 2.47 & 0.49 \\
\hline University of Valencia & 141 & 2.32 & 0.57 \\
\hline University of Corunna & 133 & 2.19 & 2.06 \\
\hline Jaume I University & 132 & 2.17 & 2.37 \\
\hline University of Alicante & 128 & 2.10 & 1.54 \\
\hline University of Cantabria & 108 & 1.78 & 1.63 \\
\hline Rey Juan Carlos University & 106 & 1.74 & 2.04 \\
\hline Autonomous University of Madrid & 103 & 1.69 & 0.49 \\
\hline University of Valladolid & 100 & 1.64 & 1.24 \\
\hline University of Malaga & 98 & 1.61 & 1.01 \\
\hline University of Huelva & 83 & 1.36 & 2.92 \\
\hline Technical University of Cartagena & 83 & 1.36 & 3.21 \\
\hline University of La Laguna & 80 & 1.31 & 0.90 \\
\hline Pablo de Olavide University & 79 & 1.30 & 2.31 \\
\hline University of Salamanca & 78 & 1.28 & 0.74 \\
\hline University of Girona & 77 & 1.27 & 1.20 \\
\hline Carlos III University of Madrid & 76 & 1.25 & 0.99 \\
\hline National Distance University & 74 & 1.22 & 1.44 \\
\hline University of La Rioja & 69 & 1.13 & 3.66 \\
\hline University of Leon & 69 & 1.13 & 1.86 \\
\hline University of Murcia & 68 & 1.12 & 4.26 \\
\hline University of Cadiz & 67 & 1.10 & 1.18 \\
\hline University of Las Palmas de Gran Canaria & 64 & 1.05 & 1.57 \\
\hline University of Alcala & 58 & 0.95 & 0.82 \\
\hline Public University of Navarra & 50 & 0.82 & 1.42 \\
\hline
\end{tabular}


An analysis of the journals where papers were published showed sustainability to be the vehicle of choice, accounting for $21 \%$ of the total, followed by the Journal of Cleaner Production and Renewable Energy (Table 2). Together, those three journals published nearly half ( $47.55 \%)$ of all the papers analysed.

Table 2. "Green \& Sustainable Science \& Technology" papers published by journal ( $>20$ papers) (Web of Science 2000-2020).

\begin{tabular}{|c|c|c|}
\hline Journal & No. Papers & $\%$ \\
\hline Sustainability & 1286 & 21.14 \\
\hline Journal of Cleaner Production & 995 & 16.35 \\
\hline Renewable Energy & 612 & 10.06 \\
\hline Renewable Sustainable Energy Reviews & 529 & 8.69 \\
\hline Green Chemistry & 336 & 5.52 \\
\hline Chemsuschem & 224 & 3.68 \\
\hline ACS Sustainable Chemistry Engineering & 185 & 3.04 \\
\hline IET Renewable Power Generation & 75 & 1.23 \\
\hline Sustainable Cities and Society & 74 & 1.22 \\
\hline Journal of Industrial Ecology & 66 & 1.08 \\
\hline International Journal of Greenhouse Gas Control & 63 & 1.04 \\
\hline Green Energy and Technology & 55 & 0.90 \\
\hline Agronomy for Sustainable Development & 53 & 0.87 \\
\hline AIP Conference Proceedings & 51 & 0.84 \\
\hline Clean Technologies and Environmental Policy & 51 & 0.84 \\
\hline Environmental Progress Sustainable Energy & 51 & 0.84 \\
\hline Journal of Sustainable Tourism & 51 & 0.84 \\
\hline Journal of Renewable and Sustainable Energy & 48 & 0.79 \\
\hline Energy Procedia & 41 & 0.67 \\
\hline IEEE Transactions on Sustainable Energy & 41 & 0.67 \\
\hline Sustainability Science & 38 & 0.62 \\
\hline Clean Soil Air Water & 32 & 0.53 \\
\hline Proceedings of the 11th ISES EuroSun Conference (2016) & 31 & 0.51 \\
\hline Sustainable Development & 30 & 0.49 \\
\hline Current Opinion in Environmental Sustainability & 29 & 0.48 \\
\hline WIT Transactions on Ecology and the Environment & 29 & 0.48 \\
\hline Agroecology and Sustainable Food Systems & 27 & 0.44 \\
\hline International Conference on Energy Environment: ICEE & 26 & 0.43 \\
\hline $\begin{array}{c}\text { International Conference on Concentrating Solar } \\
\text { Power and Chemical Energy Systems: Solarpaces (2016) }\end{array}$ & 25 & 0.41 \\
\hline International Journal of Sustainable Development and World Ecology & 25 & 0.41 \\
\hline International Journal of Sustainable Transportation & 25 & 0.41 \\
\hline Journal of Renewable Materials & 25 & 0.41 \\
\hline Papers of the 25th European Biomass Conference & 25 & 0.41 \\
\hline Energy for Sustainable Development & 24 & 0.39 \\
\hline International Renewable and Sustainable Energy Conference: IRSEC & 24 & 0.39 \\
\hline $\begin{array}{c}\text { International Conference on Concentrating Solar Power and } \\
\text { Chemical Energy Systems: Solarpaces (2017) }\end{array}$ & 23 & 0.38 \\
\hline International Journal of Sustainability in Higher Education & 23 & 0.38 \\
\hline International Conference on Renewable Energy Research and Applications & 22 & 0.36 \\
\hline Energy Efficiency & 21 & 0.35 \\
\hline Papers of the 23rd European Biomass Conference & 21 & 0.35 \\
\hline
\end{tabular}

A total of $33 \%$ of all the papers were published under open access arrangements.

Even though all the papers were published in journals listed under the category "Green \& Sustainable Science \& Technology", as some were indexed under more than one heading, a significant number of papers was also related to other categories (Figure 4). The categories most frequently observed were associated with generic scientific terms and environmental studies, although energy, engineering and chemistry also accounted for a significant proportion of the total. 


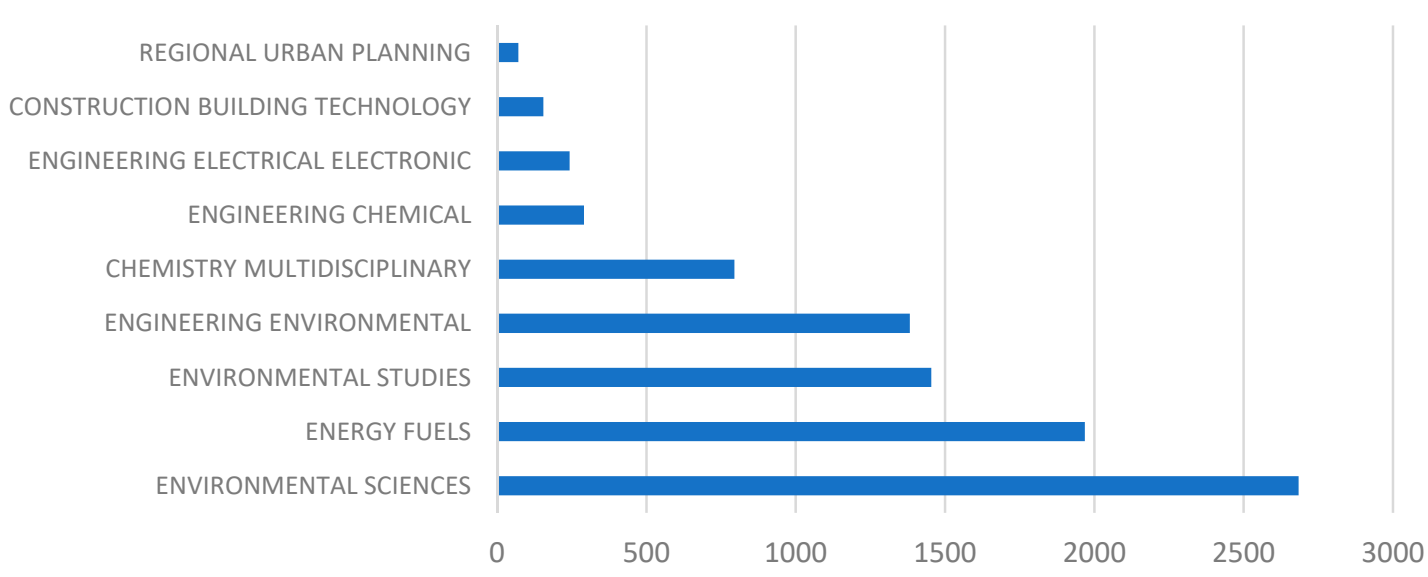

Figure 4. Distribution of output by subject category (>1\% papers) (Web of Science 2000-2019).

Based on the frequency of occurrence of keywords found in the papers, Vosviewer software generated five (colour-coded) clusters that defined the five most prominent fields in "Green \& Sustainable Science \& Technology" (Figure 5). The green cluster includes energy and more specifically renewable (solar, tidal, wind) energy-related subjects, an area closely aligned with SDG 7. The red cluster includes papers on renewable resources, such as biomass and biodiesel and other energy issues, likewise directly related to SDG 7. The violet cluster covers subjects associated with manufacturing and innovation, identified with keywords, such as companies, innovation, governance and corporate social responsibility, which lie within the scope of SDG 9. The blue cluster focuses on educational and knowledge matters, with particular emphasis on universities, health and tourism (SDGs 4 and 3). The yellow cluster, in turn, addresses responsible consumption, life cycle, carbon footprint and agriculture (SDGs 12, 2 and 13). These five fields comprise the strategic areas researched by Spanish universities, which obviously do not cover the wide spectrum of subjects defined under the 17 Agenda 2030 sustainable development goals.

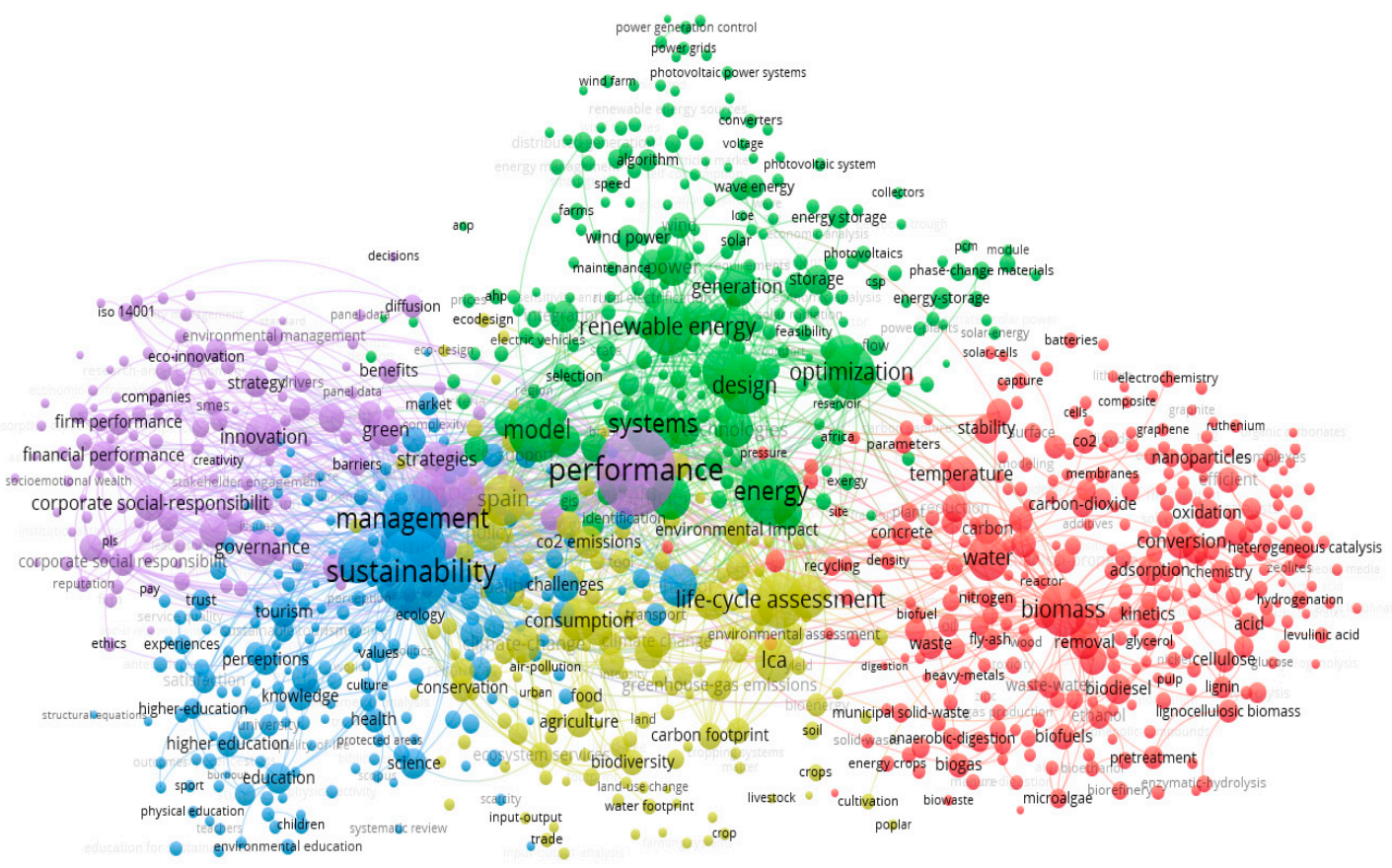

Figure 5. Distribution of output by subject cluster (Web of Science 2000-2019). 


\subsection{Social Media}

In all, $93 \%$ of the 6084 papers published by Spanish universities had a DOI and 35\% of those had mentions in at least one of the sources cited in the Altmetric.com platform. Inasmuch as the dissemination of scientific papers across social media is a recent practice, the indicators obtained refer to the last 10 years only. The number of papers with a DOI rose in that timeframe to include nearly all (Figure 6). The number mentioned in social media also grew, from 21\% in 2010 to $38 \%$ in 2019 . Although $38 \%$ may seem like a low rate, it is indicative of the progressive presence of science and research in social media.

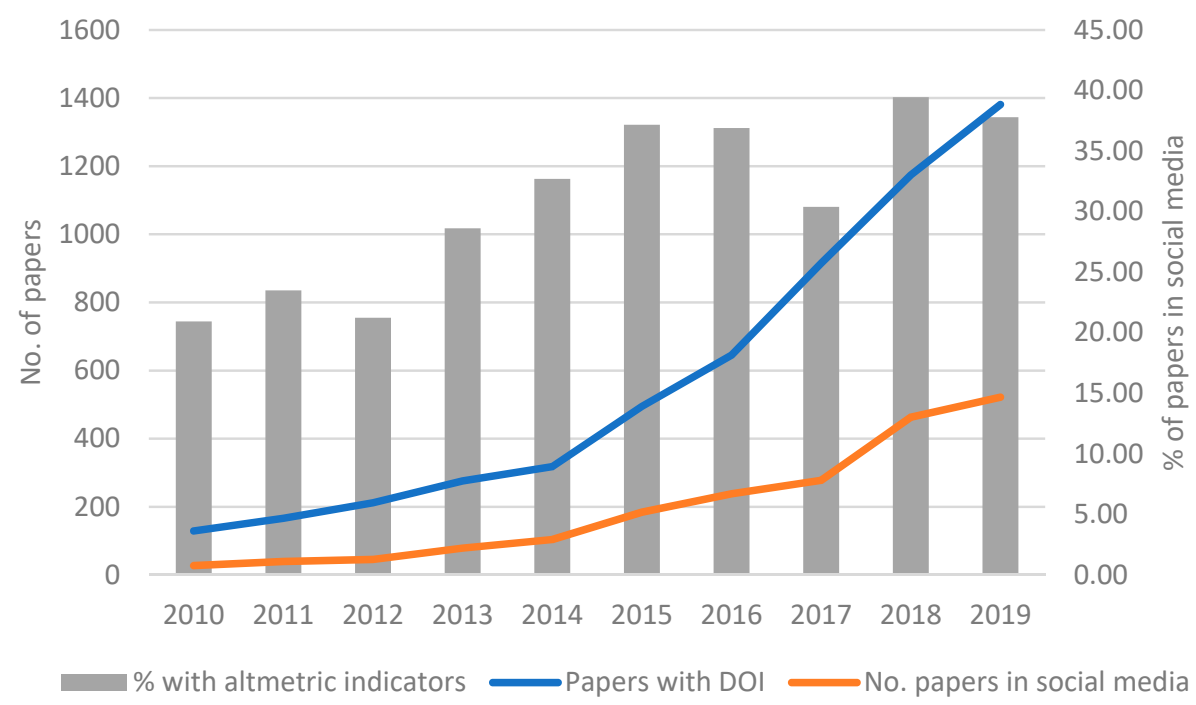

Figure 6. Number of documents mentioned in social media (Web of Science 2010-2019).

Further to the list of all the Altmetric.com sources mentioning Spanish university papers in Table 3, Twitter and Facebook were the two most prominent. The nearly 1700 papers mentioned on Twitter were referenced over 9000 times. The distribution also showed that certain papers were mentioned very frequently. Twitter stands out in the distribution graphed in Figure 7, for a single paper was tweeted 410 times. Although the number of mentions was smaller in other sources, it was significant in the written press, where a single paper received 24 (number of news outlets, and mass media: msm).

Table 3. Distribution of mentions received by Spanish university papers on sustainability.

\begin{tabular}{ccccc}
\hline Source & No. of Papers & No. of Mentions & Max Mentions & \%Total Papers \\
\hline Facebook & $\mathbf{2 7 6}$ & 345 & $\mathbf{8}$ & $\mathbf{1 4}$ \\
feeds & $\mathbf{1 1 7}$ & $\mathbf{1 4 9}$ & $\mathbf{6}$ & $\mathbf{6}$ \\
Google+ & $\mathbf{3 1}$ & $\mathbf{3 4}$ & 3 & $\mathbf{2}$ \\
forum & 0 & 0 & 0 & 0 \\
Linkedin & 2 & 3 & 2 & 0 \\
msm & $\mathbf{1 5 2}$ & $\mathbf{4 6 5}$ & $\mathbf{2 4}$ & $\mathbf{8}$ \\
peer-review & 37 & 37 & 1 & 2 \\
pinner & 0 & 0 & 0 & 0 \\
policies docs. & $\mathbf{1 4 6}$ & $\mathbf{1 6 5}$ & $\mathbf{4}$ & $\mathbf{7}$ \\
qs & 1 & 1 & 1 & 0 \\
rdts & 8 & 9 & 2 & 0 \\
rh & 2 & 2 & 1 & 0 \\
videos & 3 & 3 & $\mathbf{1}$ & $\mathbf{0}$ \\
weibo & 1 & 4 & 4 & 0 \\
Wikipedia & $\mathbf{4 4}$ & $\mathbf{5 8}$ & $\mathbf{8}$ & $\mathbf{2}$ \\
Twitter & $\mathbf{1 6 9 9}$ & $\mathbf{9 7 7 9}$ & $\mathbf{4 1 0}$ & $\mathbf{8 5 . 3 3}$ \\
\hline
\end{tabular}

Note: since a given paper may be mentioned in more than one source, the sum of the percentages of papers mentioned is greater than $100 \%$. 


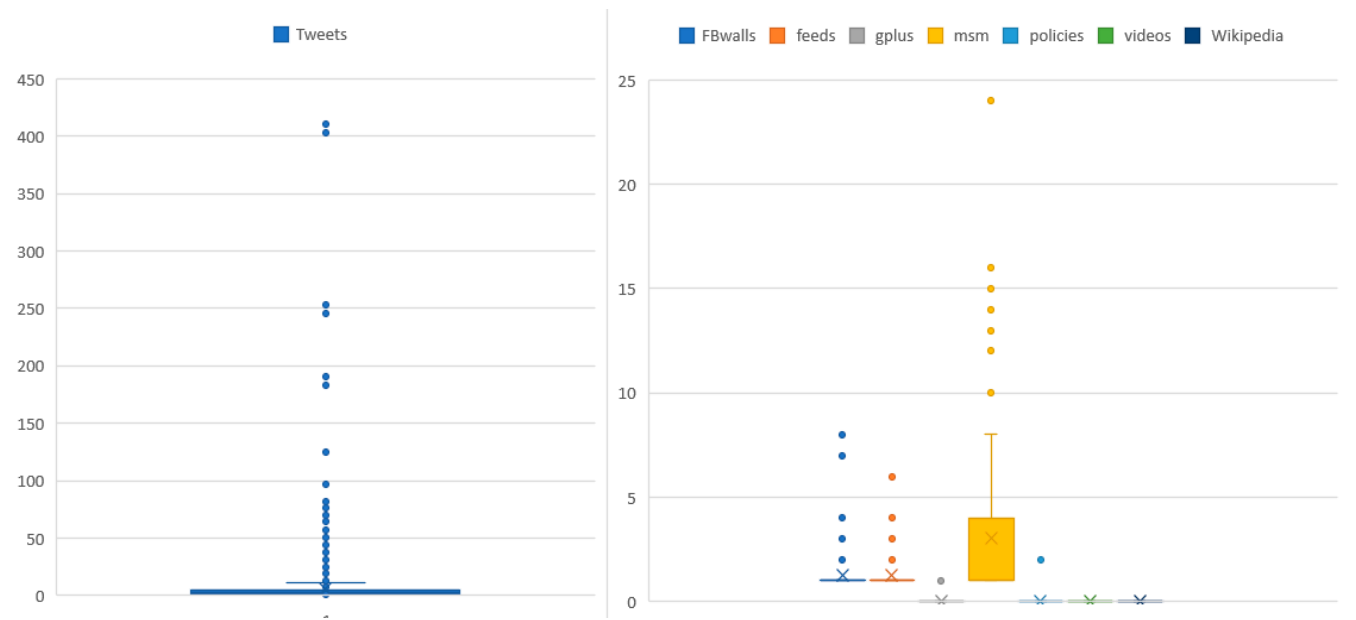

Figure 7. Distribution of social media mentions received by Spanish university papers on sustainability by source.

Table 4 lists the institutions whose sustainability output received the largest number of mentions in social media. The National Research Council continued to head the list of Spanish institutions, followed by major universities such as the Technical U. of Valencia and the Autonomous U. of Barcelona. The first 15 positions were practically the same as in Table 1 on scientific output, with minor variations in the order. Nonetheless, the position of two universities changed significantly: the University of Alicante, from position 25 to 10, and the Complutense University of Madrid from 21 to 12. These universities have good practices that consist in offering an online course aimed at its researchers on "How to improve scientific dissemination through social media".

Table 4. Distribution of papers on sustainability with social media mentions by institution ( $>35$ papers).

\begin{tabular}{ccc}
\hline Institution & Records & \% \\
\hline National Research Council (CSIC) & 204 & 10.24 \\
Technical University of Valencia (UPV) & 171 & 8.58 \\
Autonomous University of Barcelona & 151 & 7.58 \\
University of the Basque Country & 114 & 5.72 \\
Technical University of Madrid & 111 & 5.57 \\
Technical University of Catalonia & 101 & 5.07 \\
University of Seville & 85 & 4.26 \\
University of Santiago de Compostela & 78 & 3.91 \\
University of Cordoba & 77 & 3.86 \\
University of Alicante & 76 & 3.81 \\
University of Zaragoza & 67 & 3.36 \\
Complutense University of Madrid & 55 & 2.76 \\
University of Granada & 54 & 2.71 \\
University of Barcelona & 53 & 2.66 \\
University of Castille-La Mancha & 50 & 2.51 \\
University of Almeria & 48 & 2.41 \\
Jaume I University & 48 & 2.41 \\
University of Valencia & 46 & 2.31 \\
Rovira I Virgili University & 41 & 2.06 \\
Basque Foundation for Science & 40 & 2.01 \\
University of Jaen & 39 & 1.96 \\
University of Extremadura & 38 & 1.91 \\
University of Malaga & 37 & 1.86 \\
Rey Juan Carlos University & 37 & 1.86 \\
University of Vigo & 37 & 1.86 \\
University of Oviedo & 37 & 1.86 \\
CSIC UPV Institute of Chemical Technology (ITQ) & 37 & 1.86 \\
\hline
\end{tabular}


Sustainability, with $30 \%$ of its papers mentioned in at least one social media, was the journal most prevalent in those media. It was followed by the Journal of Cleaner Production (17\%) and Renewable Sustainable Energy Reviews which, like Chemsuschem, saw 8\% of their papers mentioned (Table 5). Those four journals accounted for $64.93 \%$ of all mentions.

Table 5. Distribution of papers on sustainability with social media mentions by journal (>10 papers).

\begin{tabular}{ccc}
\hline Journal & No. Pap & $\mathbf{\%}$ \\
\hline Sustainability & 602 & 30.21 \\
Journal of Cleaner Production & 341 & 17.11 \\
Renewable Sustainable Energy Reviews & 169 & 8.48 \\
Chemsuschem & 162 & 8.13 \\
Renewable Energy & 113 & 5.67 \\
Green Chemistry & 106 & 5.32 \\
ACS Sustainable Chemistry Engineering & 73 & 3.66 \\
Agronomy for Sustainable Development & 37 & 1.86 \\
Journal of Sustainable Tourism & 31 & 1.56 \\
Current Opinion in Environmental Sustainability & 30 & 1.51 \\
Journal of Renewable and Sustainable Energy & 27 & 1.35 \\
Sustainability Science & 23 & 1.15 \\
Journal of Industrial Ecology & 21 & 1.05 \\
Sustainable Cities and Society & 19 & 0.95 \\
Clean Soil Air Water & 18 & 0.90 \\
Nature Sustainability & 15 & 0.75 \\
International Journal of Greenhouse Gas Control & 15 & 0.75 \\
Energy Procedia & 14 & 0.70 \\
Agroecology and Sustainable Food Systems & 14 & 0.70 \\
Sustainable Development & 14 & 0.70 \\
Energy for Sustainable Development & 12 & 0.60 \\
IET Renewable Power Generation & 12 & 0.60 \\
\hline
\end{tabular}

An intriguing relationship was also identified between open access and impact in social media, for nearly $50 \%$ of the open access papers were mentioned in at least one network.

\section{Discussion and Conclusions}

The findings of this study, which afford detailed information on how Spanish universities communicate their sustainability activities, serve as grounds for answering the research questions posed. The results obtained contribute to the identification of sustainability indicators applicable to universities in different countries and geographical areas. The elaboration of sustainability rankings, such as GrenMetric, usually uses little contrasted information provided by the universities themselves. Therefore, identifying indicators, such as those proposed in this article, would make it possible to obtain objective information to establish reliable comparisons related to the commitment of universities to sustainability.

Like other institutions in Europe and the world in general, Spanish universities have been gradually adopting sustainable practices in terms of both policy and research [45], and raising their scientific output on the subject substantially. Bibliometric studies and institutional document analysis attest to intensified interest in sustainability among Spanish universities in recent years. Some authors [33] find obvious proof of that interest in the growing number of scientific papers and courses on sustainable development as well as in participation in European projects. Although consistently steady, growth took a steep upturn in 2015 after 193 UN member countries approved Agenda 2030 and its 17 SDGs. The present findings are consistent with that trend, for nearly $70 \%$ of all the articles analysed were published in the last 5 years. Similar results have been reported [46,47]. Overall, they would appear to indicate that Spanish universities are exhibiting sensitivity to addressing the worldwide challenges defined by the United Nations in their research agendas. 
The upward trend in interest in sustainability is likewise consistent with the present findings on the titles of deputy vice-chancellorships or positions entrusted with sustainability management in Spanish universities. A comparison of the titles prevailing in 2020 to those listed in the review by Barañano [31] revealed an increase in the number of universities using terms associated with sustainability to designate these governing bodies. The frequency of terms such as "equality", "healthful" and "diversity" was also observed to rise, to the detriment of more generic terminologies, such as "environment", whose presence declined. The findings seem to infer that the appearance of Agenda 2030 is visibly changing the ideas pursued and terminologies used by universities in connection with image and communication as well as research priorities and agendas. Although their institutional websites contain no specific page on Agenda 2030, a significant $60 \%$ of Spanish universities furnish information on the issues covered. Those data suggest that Spanish universities are indisputably transitioning toward sustainability. As in other countries' institutions, however, much ground has yet to be covered before they reach the ultimate goal of holistically integrating all dimensions of sustainability in their management, research and knowledge transfer activities. However, there are universities that are advancing in the development of comprehensive, well-integrated sustainability programs, as shown by Blackburn [43]. In this process (development and practice of sustainability in universities) special attention should be given to students' environmental education programs in order to develop their engagement with sustainability [36,48-50], both within and outside the university context.

The identification of new indicators to assess and compare the situations across universities, in turn, is one of the major challenges to be confronted in the years to come, for it would shed light on the efforts underway at universities to research and advance in terms of the UN's 17 sustainable development goals [51]. The present study also uses an activity index (AI) to identify universities that devote more effort to research on sustainability than to research as a whole. That indicator, traditionally used in bibliometrics [52] to determine the degree of a university's specialisation in a given field, is particularly apt here to measure output on sustainability. Seven Spanish universities were identified with output greater than $3 \%$ of the total. Although smaller and characterised by lower total scientific output, those institutions exemplify the trend to prioritise subject areas and devote more resources to sustainability-related research.

Both this study and the research conducted by González et al. [47] identified Sustainability and the Journal of Cleaner Production as the publications carrying the largest share of Spanish universities' research articles on sustainability. This study found that over $37 \%$ of the papers analysed appeared in those two publications, which were found to play a significant role in disseminating more general or inter-disciplinary papers on the subject.

The results also provide some insight into which of the sustainable development goals (SDGs) are rousing greatest research interest in Spanish universities. Cluster analysis defined five major subject areas closely related to a number of Agenda 2030 SDGs: 7 (renewable energy), 9 (innovation and governance), 4 (quality education), 3 (health and well-being), 12 (sustainable consumption), 2 (zero hunger) and 13 (climate action). A more precise analysis of the terminology used in the articles might support their association with one or several SDGs for a more systematic determination of the areas of research involved. This study identified very few references to more socially-geared SDGs such as 1 (poverty), 5 (gender equality) and 8 (wealth inequality), or those with a biological dimension, such as 14 (marine diversity) and 15 (terrestrial ecosystems). The inference might be that those areas carry less weight in universities' research endeavour. While that finding may mirror reality to some extent, this study is also subject to certain obvious limitations in terms of subject analysis, insofar as it attributes greater weight to energy, technology and engineering, areas where Spain's technical universities (UPV, UPM, PUC) rank highly. Sustainability is a very broad term that covers many and diverse fields of science. Studies in greater depth are consequently in order to seek new bibliometric strategies to more precisely determine the overall research efforts underway at Spanish universities in connection with the SDGs as a whole. 
Considering the strategies that universities deploy to communicate their sustainability-related activities to society, it might be noted in that regard that to provide an account of what they do to drive sustainability and respond to social concerns, universities must convey their message to a larger audience uninvolved in academic and scientific circuits. That entails publishing their research findings outside of specialised journals with a very limited readership, i.e., resorting to other communication and dissemination vehicles.

One way to assess interest in sustainability is to review media news [53] in pursuit of a causal relationship between the priority granted some matters and the importance attached by citizens to social issues [54]. A recent study [55] used topic model methodology to show that the written press has been echoing Spanish universities' sustainability-related activities in recent years. The study identified nine sustainability dimensions or subjects of particular interest to the media and presumably to readers. Nonetheless, newspapers as sources of information on and vehicles for dissemination of scientific knowledge among the public at large have been eclipsed in the last 10 years by the extensive use of the internet as a channel for influencing public opinion [56]. The internet and specifically institutional websites have acquired pre-eminence in minute-by-minute reporting of information in an attempt to respond to citizens' interests and doubts (as seen recently in connection with COVID-19, a matter closely tracked and extensively addressed on university websites).

The internet has become an important tool for informing about sustainability matters, especially where large audiences are targeted [35]. Corporate websites are among the communication channels most commonly used by the world's largest companies for such disclosure [57-59]. Website communication has now become the primary strategy deployed by organisations to build an institutional reputation and define their brand image [60], an observation extensive to communication on sustainability. Analogously, institutional websites are being used by higher education institutions (HEIs) to share information and engage the campus community in sustainability efforts [35-37,44,61-63]. Websites can fuel interaction, networking and communication among students, staff, stakeholders and the community [64]. Their significance as a source of data on environmental issues and sustainability is also growing [65].

As noted above, recent research has analysed university websites in several countries [35-37,63]. The present study aimed to supplement earlier work by furnishing information on 50 Spanish universities' websites on the grounds of 15 indicators grouped under three subject headings. The findings showed that $26 \%$ of Spanish universities furnish information on sustainability on their home pages and a further $50 \%$ on the objectives and mission page. Those percentages are slightly higher than the $67 \%$ observed for Canadian universities [37] and considerably higher than found for U.S. institutions 7 years prior [35]. Data on the publication of sustainability plans followed a similar pattern, with $22 \%$ for Canadian and $40 \%$ for Spanish universities. Those results attest to the growing trend among universities in different countries to use their websites to report progress in sustainability. Although the content on those sites may not necessarily provide a wholly accurate picture of institutional realities, it is nonetheless a window through which to view university performance in that regard.

The present findings on the impact of sustainability research in the media show that it is greater in social media for papers on sustainability published in open access journals than for those appearing in subscription-only journals. That observation is consistent with results reported by other authors [66,67]. Only one of the journals heading the list described here, Sustainability, is an open access publication. The others tend to publish a variable proportion of the papers they carry in open media format (gold or green access). If the ultimate aim is to enhance the visibility of science, universities should view open access not as a recommendation but as an obligation.

Twitter $(85 \%)$ and Facebook (14\%) were recognised here as the social media most actively disseminating sustainability research, as revealed earlier by studies in which Altmetric.com was the source of information $[68,69]$. Mentions in social media were observed to have grown significantly in the last 10 years, with $38 \%$ of the sustainability papers receiving such attention, compared to $21 \%$ in 
2010. Whilst the former percentage may seem fairly low, it is much higher than observed for areas such as physics or engineering, with figures of no more than $21 \%$. In other fields, such as plant science, the percentages observed stand at around $31 \%$ and in communication up to $43 \%$. Some earlier studies analysing the impact of all disciplines in social media reported that the percentage of papers with altmetric indicators normally ranges from $15 \%$ to $24 \%$, with social sciences and humanities exhibiting the highest values [70]. Around $21 \%$ of the articles on energy savings have been observed to be present in social media [64], a value consistent with earlier data on the overall impact of papers listed in the Web of Science [62].

The present analysis of university websites showed that only $30 \%$ had social media accounts and only $6 \%$ blogs specifically designed to disseminate their sustainability activities. Such figures differ widely from those observed for Canadian universities [37], 50\% to 59\% of which had Twitter or Facebook accounts and $12.5 \%$ blogs specifically dealing with sustainability. Up to $16 \%$ of U.S. universities, in turn, run such specific blogs [44]. A more precise breakdown of the present data revealed that social media impact was greatest in two universities, U. Alicante and Complutense U. of Madrid. The communication and dissemination departments of those two institutions are in all likelihood applying dissemination strategies that may serve as a model for other universities.

By way of summary, Spanish universities have yet to fully address the challenge of adopting social media as effective communication tools and an avenue for furthering sustainable behaviour both in the university community and society at large. That opinion is shared by some authors [71,72]. Universities should naturally prioritise sustainability, but it is also important to convey their achievements to society at large. At the same time, indicators to assess the impact of such communication would prove to be useful in this context. The shared aim is to identify good practice to enable all universities to convey their research findings to society with greater immediacy and agility to drive more effective and rapid change toward sustainability.

Following the results obtained, we propose some recommendations to make communication about the different practices related to sustainability more visible: keep information updated on the institution's webpage, use precise keywords for effective information retrieval, offer objective information to university rankings, publish in open access journals (or deposit publications in repositories to make them accessible) and have an institutional communication policy that disseminates the main advances in sustainability in the mass-media and social media.

Finally, it is important to mention some limitations. Firstly, the study has focused on the analysis of the information provided by the websites of Spanish universities. We are aware that this is an indirect measurement of the sustainability of the universities and we consider it essential to establish the relationship that exists between sustainability reporting through the websites and real actions. Therefore, it is our intention to identify quantifiable aspects of the real implementation of sustainability in Spanish universities in future studies. We are also aware that the information collected through websites or scientific publications is only a "visible" part of the activity of universities. However, there are also many "invisible" practices related to sustainability that we cannot account for, such as: research projects, training activities, dissemination actions, among others. At the same time, the study of publications related to sustainability is a conceptual cutback that, evidently, leaves out of the analysis those papers published in journals on other subjects. However, in spite of these limitations, this study attempts to propose a methodology that offers an approach to the analysis of formal activities related to sustainability and allows us to take as a case example the situation of Spanish universities but which can also be applied to other contexts.

Author Contributions: Conceptualization, D.D.F.; J.B. and F.S.; methodology, D.D.F.; J.B.; F.S.; software, D.D.F.; formal analysis, D.D.F., K.P.; investigation, D.D.F., J.B., K.P., F.S.; writing—original draft preparation, D.D.F.; F.S.; writing-review and editing, J.B.; visualization, D.D.F., K.P.; project administration, F.S. All authors have read and agreed to the published version of the manuscript.

Funding: This research was funded by the Madrid Regional Government and the European Social Fund, Project "Towards the Consolidation of Inclusive Cities: A Challenge for Madrid" (H2019/HUM-5744). 
Conflicts of Interest: The authors declare no conflict of interest.

\section{References}

1. Eurostat. Tertiary Education Statistics. Online Publications. 2020. Available online: https://ec.europa.eu/eur ostat/statistics-explained/index.php/Tertiary_education_statistics (accessed on 12 August 2020).

2. Unesco. Contributing to a More Sustainable Future: Quality Education, Life Skills and Education for Sustainable Development. 2005. ED/PEQ/IQL/2005/PI/H/2. Available online: https://unesdoc.unesco.org/ark: /48223/pf0000141019 (accessed on 25 July 2020).

3. Barra, C.; Zotti, R. Investigating the human capital development-growth nexus does the efficiency of universities matter? Int. Reg. Sci. Rev. 2017, 40, 638-678. [CrossRef]

4. Findler, F.; Schönherr, N.; Lozano, R.; Stacherl, B. Assessing the impacts of higher education institutions on sustainable development. An analysis of tools and indicators. Sustainability 2018, 11, 59.

5. Findler, F.; Schönherr, N.; Lozano, R.; Reider, D.; Martinuzzi, A. The impact of higher education institutions on sustainable development. A review and conceptualization. Int. J. Sustain. High. Educ. 2019, 20, $23-38$. [CrossRef]

6. Lozano, R.; Lozano, F.J.; Mulder, K.; Huisingh, D.; Waas, T. Advancing higher education for sustainable development: International insights and critical reflections. J. Clean. Prod. 2013, 48, 3-9. [CrossRef]

7. Ragazzi, M.; Ghidini, F. Environmental sustainability of universities: Critical analysis of a green ranking. Energy Procedia 2017, 119, 111-120. [CrossRef]

8. Aleixo, A.M.; Leal, S.; Azeiteiro, U.M. Conceptualization of sustainable higher education institutions, roles, barriers, and challenges for sustainability: An exploratory study in Portugal. J. Clean. Prod. 2018, 172, 1664-1673. [CrossRef]

9. Akins, E.; Giddens, E.; Glassmeyer, D.; Gruss, A.; Hedden, M.; Slinger-Friedman, V.; Weand, M. Sustainability education and organizational change: A critical case study of barriers and change drivers at a higher education institution. Sustainability 2019, 11, 501. [CrossRef]

10. Caeiro, S.; Sandoval, A.; Martins, R.; Bayas, C. Sustainability assessment and benchmarking in higher education institutions. A critical reflection. Sustainability 2020, 12, 543. [CrossRef]

11. Alexa, L.; Maier, V.; Serban, A.; Craciunescu, R. Engineers changing the world: Education for sustainability in Romanian technical universities-An empirical web-based content analysis. Sustainability 2020, 12, 1983. [CrossRef]

12. Wolff, L.; Ehrström, P. Social sustainability and transformation in higher educational settings: A utopia or possibility? Sustainability 2020, 12, 4176. [CrossRef]

13. Cortese, A.D. The critical role of higher education in creating a sustainable future. Plan. High. Educ. 2003, 31, $15-22$.

14. Alshuwaikhat, H.M.; Abubakar, I. An integrated approach to achieving campus sustainability: Assessment of the current campus environmental management practices. J. Clean. Prod. 2008, 16, 1777-1785. [CrossRef]

15. López, I.L.; Bote, M.; Rives, L.M.; Bañon, A.R. Higher education institutions as a transformation platform under the sustainable development goals framework. Eur. J. Sustain. Dev. 2019, 8, 306. [CrossRef]

16. Lozano, R. The state of sustainability reporting in universities. Int. J. Sustain. High. Educ. 2011, 12, 67-78. [CrossRef]

17. WCED. Our Common Future; Oxford University Press: Oxford, UK, 1987.

18. Ralph, M.; Stubbs, W. Integrating environmental sustainability into universities. High. Educ. 2014, 67, 71-90. [CrossRef]

19. Grindsted, T. Sustainable universities-From declarations on sustainability in higher education to national law. Environ. Econ. 2011, 2, 29-36. [CrossRef]

20. Lozano, R.; Lukman, R.; Lozano, F.J.; Huisingh, D.; Lambrechts, W. Declarations for sustainability in higher education: Becoming better leaders, through addressing the university system. J. Clean. Prod. 2013, 48, 10-19. [CrossRef]

21. Naciones Unidas. Sustainable Development Goals. 2020. Available online: https://www.un.org/sustainable development/ (accessed on 15 June 2020).

22. Wright, T.; Horst, N. Exploring the ambiguity: What faculty leaders really think of sustainability in higher education. Int. J. Sustain. High. Educ. 2013, 14, 209-227. [CrossRef] 
23. Beynaghi, A.; Moztarzadeh, F.; Maknoon, R.; Waas, T.; Mozafari, M.; Hugé, J.; Leal Filho, W. Towards an orientation of higher education in the post Rio +20 process: How is the game changing. Futures 2014, 63, 49-67. [CrossRef]

24. Leal Filho, W.; Raath, S.; Lazzarini, B.; Vargas, V.R.; De Souza, L.; Anholon, R.; Quelhas, O.L.G.; Haddad, R.; Klavins, M.; Orlovic, V.L. The role of transformation in learning and education for sustainability. J. Clean. Prod. 2018, 199, 286-295. [CrossRef]

25. Velazquez, L.; Munguia, N.; Platt, A.; Taddei, J. Sustainable university: What can be the matter? J. Clean. Prod. 2006, 14, 810-819. [CrossRef]

26. Sandoval Hamón, L.A.; Bayas Aldaz, C.B.; Rodríguez Pomeda, J.; Sánchez Fernández, F.; Casani Fernández de Navarrete, F. From ecocity to ecocampus: Sustainability policies in university campuses. Int. J. Sustain. Dev. Plan. 2016, 12, 541-551. [CrossRef]

27. Blanco-Portela, N.; Pertierra, L.; Benayas, J.; Lozano, R. Sustainability leaders' perceptions on the drivers for and the barriers to the integration of sustainability in Latin American higher education institutions. Sustainability 2018, 10, 2954. [CrossRef]

28. Stephens, J.; Hernandez, M.; Roman, M.; Graham, A.; Scholz, R. Higher education as a change agent for sustainability in different cultures and contexts. Int. J. Sustain. High. Educ. 2008, 9, 317-338. [CrossRef]

29. Lozano, R. Incorporation and institutionalization of SD into universities: Breaking through barriers to change. J. Clean. Prod. 2006, 14, 787-796. [CrossRef]

30. Sepasi, S.; Rahdari, A.; Rexhepi, G. Developing a sustainability reporting assessment tool for higher education institutions: The University of California. Sustain. Dev. 2018, 26, 672-682. [CrossRef]

31. Barañano, M. La Responsabilidad Social Como Misión en Las Universidades Españolas Y Su Contribución Al Desarrollo Sostenible. Diagnóstico Y Buenas Prácticas. 2011. Available online: https://www.researchgate.net/publication/344380480_la_responsabilidad_social_como_mision_en_las_universi dades_espanolas_y_su_contribucion_al_desarrollo_sostenible_diagnostico_y_buenas_practicas (accessed on 5 July 2020).

32. CRUE. Diagnóstico de la Sostenibilidad Ambiental de las Universidades. 2019. Available online: http://www.crue .org/Documentos\%20compartidos/Sectoriales/Sostenibilidad/GESU-informe-sostenibilidad-2019.pdf (accessed on 5 July 2020).

33. De Filippo, D.; Sandoval-Hamón, L.A.; Casani, F.; Sanz-Casado, E. Spanish universities' sustainability performance and sustainability-related R \& D+ I. Sustainability 2019, 11, 5570.

34. Herremans, I.M.; Nazari, J.A.; Mahmoudian, F. Stakeholder relationships, engagement, and sustainability reporting. J. Bus. Ethics 2016, 138, 417-435. [CrossRef]

35. Dade, A.; Hassenzahl, D. Communicating sustainability. A content analysis of website communications in the Unites States. Int. J. Sustain. High. Educ. 2013, 14, 254-263. [CrossRef]

36. Son-Turan, S.; Lambrechts, W. Sustainability disclosure in higher education. A comparative analysis of reports and websites of public and private universities in Turkey. Int. J. Sustain. High. Educ. 2019, 20, 1143-1170. [CrossRef]

37. Amey, L.; Plummer, R.; Pickering, G. Website communications for campus sustainability: An analysis of Canadian universities. Int. J. Sustain. High. Educ. 2020, 21, 531-556. [CrossRef]

38. CRUE. La Universidad Española en cifras 2017-2018. 2019. Available online: http://www.crue.org/Documento s\%20compartidos/Publicaciones/Universidad\%20Espa\%C3\%B1ola\%20en\%20cifras/UEC\%201718_FINAL_D IGITAL.pdf (accessed on 5 July 2020).

39. Universitas de Indonesia. GreenMetric World University Ranking. 2020. Available online: http://greenmetri c.ui.ac.id/what-is-greenmetric/ (accessed on 5 July 2020).

40. Egghe, L.; Rousseau, R. Introduction to Informetrics: Quantitative Methods in Library, Documentation and Information Science; Elsevier Science Publishers: Amsterdam, The Netherlands, 1990.

41. Callon, M.; Courtial, J.-P.; Penan, H. Cienciometría: La Medición de la Actividad Científica: De la Bibliometría a la Vigilancia Tecnológica; Trea: Asturias, Spain, 1995.

42. Mohammadi, E.; Thelwall, M. Assessing the Mendeley readership of social sciences and humanities research. In Proceedings of the 14th International Conference of the International Society for Scientometrics and Informetrics (ISSI), Vienna, Austria, 15-19 July 2013; pp. 200-214.

43. De Filippo, D.; Serrano-López, A. From academia to citizenry. Study of the flow of scientific information from projects to scientific journals and social media in the field of "Energy saving". J. Clean. Prod. 2018, 199, 248-256. [CrossRef] 
44. Ott, H.; Wang, R.; Bortree, D. Communicating sustainability online: An examination of corporate, nonprofit, and university websites. Mass Commun. Soc. 2016, 19, 671-687. [CrossRef]

45. Alba, D.; Benayas, J.; Gutierrez, J. Towards a definition of environmental sustainability evaluation in higher education. High. Educ. Policy 2018, 31, 447-470. [CrossRef]

46. Bautista-Puig, N.; Aleixo, A.M.; Leal, S.; Azeiteiro, U.; Costas, R. Unveiling the research landscape of sustainable development goals and their inclusion in higher education institutions and research centers: Major trends in 2000-2017. arXiv 2020, arXiv:2002.04895.

47. González, E.; Colomo, E.; Cívico, A. Quality education as a sustainable development goal in the context of 2030 agenda: Bibliometric approach. Sustainability 2020, 12, 5884. [CrossRef]

48. Blackburn, W. The practice of sustainability at colleges and universities. Environ. Law Rep. News Anal. 2016, 46, 10394-10415.

49. Yazici, N.; Babalik, A. Determination of environmental awareness of university students: The case of Suleyman Demirel University (SDU). Environ. Earth Sci. 2016, 75, 1-8. [CrossRef]

50. Richter, B.W.; Sousa, L.O.D. The implementation of environmental education to promote sustainability: An overview of the processes and challenges. Int. J. Sustain. Dev. World Ecol. 2019, 26, 721-731. [CrossRef]

51. Alba, D.; Benayas, J.; Blanco, N. Cómo Evaluar Los ODS en Las Universidades; RSU: Madrid, Spain, 2020; ISBN 978-84-09-19610-4.

52. Schubert, A.; Glänzel, W.; Braun, T. World flash on basic research: Scientometrics datafiles. A comprehensive set of indicators on 2649 journals and 96 countries in all major science fields and subfields, 1981-1985. Scientometrics 1989, 16, 3-478. [CrossRef]

53. Schmidt, A.; Ivanova, A.; Schaefer, M.S. Media attention for climate change around the world: A comparative analysis of newspaper coverage in 27 countries. Glob. Environ. Chang. 2013, 23, 1233-1248. [CrossRef]

54. Kiousis, S.; McCombs, M. Agenda-setting effects and attitude strength: Political figures during the 1996 presidential election. Commun. Res. 2004, 31, 36-57. [CrossRef]

55. Bayas, C.; Rodríguez-Pomeda, J.; Sandoval, A.; Casani, F. Understanding the university-sustainability link through media: A Spanish perspective. Sustainability 2020, 12, 4830. [CrossRef]

56. Nelkin, D.; Elias, J. Selling science: How the press covers science and technology. J. Public Health Policy 1996, 17, 501-503.

57. Gocer, A.; Tugrul, T. How brans communicate sustainability messages in emerging markets: A content analysis bases on corporate websites and social media. In Handbook of Research on Developing Sustainable Value in Economics, Finance, and Marketing; IGI Global: Pennsylvania, PA, USA, 2015; pp. 47-62.

58. Sobhani, F.; Amran, Z.; Zainuddin, Y. Sustainability disclosure in annual reports and websites: A study of the banking industry in Bangladesh. J. Clean. Prod. 2012, 23, 75-85. [CrossRef]

59. Siano, A.; Conte, F.; Amabile, S.; Vollero, A.; Piciocchi, P. Communicating sustainability: An operational model for evaluating corporate websites. Sustainability 2016, 8, 950. [CrossRef]

60. Barreda, A.; Bilgihan, A.; Nusair, K.; Okumus, F. Online branding: Development of hotel branding through interactivity theory. Tour. Manag. 2016, 57, 180-192. [CrossRef]

61. Kang, S.; Norton, H.E. Colleges and universities' use of the world wide web: A public relations tool for the digital age. Public Relat. Rev. 2006, 32, 426-428. [CrossRef]

62. Ferrer-Balas, D.; Adachi, J.; Banas, S.; Davidson, C.I.; Hoshikoshi, A.; Mishra, A.; Motodoa, Y.; Onga, M.; Ostwald, J. An international comparative analysis of sustainability transformation across seven universities. Int. J. Sustain. High. Educ. 2008, 9, 295-316. [CrossRef]

63. Hart, T.; Fox, C.; Ede, K.; Korstad, J. Do, but don't tell. The search for social responsibility and sustainability in the websites of the top-100 US MBA programs. Int. J. Sustain. High. Educ. 2015, 16, 706-728. [CrossRef]

64. Buhalis, D.; O'Connor, P. Information communication technology revolutionizing tourism. Tour. Recreat. Res. 2005, 30, 7-16. [CrossRef]

65. Bortree, D.S.; Seltzer, T. Dialogic strategies and outcomes: An analysis of environmental advocacy groups' Facebook profiles. Public Relat. Rev. 2011, 35, 317-319. [CrossRef]

66. Bruns, A.; Stieglitz, S. Quantitative approaches to comparing communication patterns on Twitter. J. Technol. Hum. Serv. 2012, 30, 3-4. [CrossRef]

67. De Filippo, D.; Silva, P.; Borges, M.M. Caracterización de las publicaciones de España y Portugal sobre Open Science y análisis de su presencia en las redes sociales. Rev. Española de Doc. Científica 2019, 42, e235. [CrossRef] 
68. Robinson-García, N.; Torres-Salinas, D.; Zahedi, Z.; Costas, R. New Data, New Possibilities: Exploring the Insides of Altmetric.Com. arXiv 2014, arXiv:1408.0135. [CrossRef]

69. Haustein, S.; Costas, R.; Larivi ere, V. Characterizing social media metrics of scholarly papers: The effect of document properties and collaboration patterns. PLoS ONE 2015, 10, e0120495. [CrossRef]

70. De Filippo, D.; Sanz-Casado, E. Bibliometric and altmetric analysis of three social science disciplines. Front. Res. Metr. Anal. 2018, 3, 34. [CrossRef]

71. Carpenter, S.; Takahashi, B.; Cunningham, C.; Lertpratchaya, A.P. The roles of social media in promoting sustainability in Higher Education. Int. J. Commun. 2016, 10, 4863-4881.

72. Joosse, S.; Brydges, T. Blogging for sustainability: The intermediary role of personal green blogs in promoting sustainability. Environ. Commun. 2018, 12, 686-700. [CrossRef]

(C) 2020 by the authors. Licensee MDPI, Basel, Switzerland. This article is an open access article distributed under the terms and conditions of the Creative Commons Attribution (CC BY) license (http://creativecommons.org/licenses/by/4.0/). 